\title{
MOSQUITO LIFE IN SURREY DURING 1921.
}

\author{
By Lt.-Col. S. P. JAMEs, I.M.S. (retd.),
}

Ministry of Health.

Mr. Malcolm E. MacGregor's interesting paper, "The Influence of Drought upon Mosquito Life in Surrey" (Bull. Ent. Res. xii, p. 205), has led me to examine our records of observations made in that county in connection with inquiries into indigenous malaria in England. As regards certain areas of the county during the past year, our expenence of the scarcity of some kinds of mosquitos is the same as Mr. MacGregor's, but (if it is desired to draw conclusions for the county as a whole) it seems important also to note that there are other areas in which the findings differ from those in the particular locality upon which he reported. Dorking, Epsom and Arbrook Common, which are within a few miles of Wisley, are examples of such areas. In these and some other localities in the county we have obtained larvae of $A$. bifurcatus without difficulty throughout the year. At Epsom, large numbers of larvae of this species in the fourth instar were found early in February this year in a well-shaded permanent pool, which we have examined regularly since 1917, and adults were caught in the open in April. Larvae were numerous throughout the year, and adults, both male and female, were captured in the open as late as 22nd October. At Dorking, larvae of bifurcatus were plentiful in several natural collections of water throughout the year. One of them-the "Mill Ponds stream"-is only 100 yards from a row of houses; another-the "Stonebridge stream"-yielded bifurcatus larvae on 19th August at every place examined along a stretch of 400 yards. On the same day many larvae of this species were found, along with larvae of $C$. pipiens, in the rainwater barrel of a house about 200 yards from the stream.

Next, as regards $A$. plumbeus and Finlaya geniculala, we have collected larvae of both species from tree-holes at Dorking and Box Hill on many occasions since the middle of August. Again, the incidence of Theobaldia annulata and Ochlerotatus nemorosus at Dorking and other localities differed this year from that in Mr. MacGregor's area. Adults of Theobaldia annulata were caught in a bedroom at Dorking during July, and larvae have been plentiful in a large stagnant ditch throughout the year. Also it is worthy of note that my laboratory assistant (P. G. Shute) collected from Arbrook Common in June a larva of a species (Aëdes cinereus) which is not included in Mr. MacGregor's list of the species found at Wisley.

As regards $A$. maculipennis, Mr. MacGregor records the important observation that, when nearly all the available breeding-places in his area were dry, there was an increase in the actual numbers of larvae found in the breeding-places which remained. As well as similar findings, our records contain the observation that this year the river Wey, at Guildford, for the first time since we began to examine it in 1918, harboured many maculipennis larvae. During July and August, my laboratory assistant, using a boat, collected numerous specimens along both banks of the river over a distance of a mile.

This and other observations in Surrey and Kent lead us to believe that the presence in our area of permanent breeding-places of various kinds sufficiently explains the differences between the records for our area and for the area examined by Mr. MacGregor. In India, where long periods of drought recur annually, the relative. 
importance of permanent and temporary breeding-places has been worked out in detail. The account on pages 82-83 of Major Christophers' report on "Malaria in the Punjab"** shows clearly, I think, that what Mr. MacGregor has described as happening in his area this year is what happens each year in certain large tracts of that country. With respect to the various mosquitos which are indigenous in an area, Major Christophers pointed out that, however hard pressed by drought some of them may be in a particular part of the area, it is always possible to find, within their usual distance of spread, some permanent collections of water in which they are breeding freely. Also, that when temporary breeding-places reappear, the various species spread widely from these permanent sources (which he calls "mosquito sanctuaries") until in a short time they can be found again throughout the area. This explains the well-established Indian observation that a particularly dry year has no permanent effect in reducing Anopheles mosquitos. In the Punjab the chief Anopheles "sanctuaries" were found to be:-(1) Large river-beds like those of the Jumna, Beas, etc. ; (2) jheels and large tanks filled with aquatic vegetation, with their associated swamps and pools; (3) extensive brickfields and large excavated pits near towns and villages; (4) irrigation systems.

Nearly the same headings would be applicable to the permanent mosquito "sanctuaries" in Surrey and Kent. As some of them exist within a few miles of the area reported on by Mr. MacGregor, a probable answer, based on Indian experience, can already be given to his question whether the species dealt with will be rare in his locality during future years.

* Scientific Memoirs by Medical Officers of the Government of India, New Series No. 46, 1911. 